ISSN 1027-5495. Functional Materials, 24, No.1 (2017), p. 82-90

\title{
Experimental study on mechanical behavior of RPC circular columns confined by high-strength stirrups under axial compression
}

\author{
Ming-Yang Chen, Wen-Zhong Zheng, Xiao-Meng Hou \\ Department of Civil Engineering, Harbin Institute of Technology, Harbin, \\ HeiLongJiang150090, China
}

Received November 25,2016

\begin{abstract}
The axial compression mechanical behavior of Reactive Power Concrete (RPC) circular columns which confined by the spiral hoop of yield strength $600 \mathrm{MPa}$ are tested, and the tie spacing and volume tie ratio were used to evaluate the RPC columns failure modes, load-displacement relationship and yield characteristics of high-strength stirrups. The results show that the peak stress of the $250 \mathrm{~mm}$ diameter circular column with no reinforcement can be up to $144.4 \mathrm{MPa}$ but with brittle failure mode, and the large volume tie ratio can increase the peak stress to $180 \mathrm{MPa}$ and failure by ductility; also, the high-strength spiral stirrups do not yield at the peak axial load, and the effective confined stress should be calculated according to the measured stirrups strain , and the remaining strength can be ensured the good ductility of the RPC specimens before reaching the ultimate failure mode; the peak strength and strain of RPC are proportional to linearly increase with effective confinement stress, but the proportion coefficient is smaller than that of ordinary concrete. The decline section of RPC stress-strain curve becomes smooth with the increase of effective binding stress, and the ductility coefficient of displacement gradually satisfies the ductility design requirements. The measured RPC stress-strain curve agrees well with the confined concrete Mander model and can be used conservatively. According to the test results, the calculation formula and the construction measurements of the axial compression capacity of the RPC with the spiral stirrup confined are put forward, which is convenient for the popularization and application of the confined RPC columns in the practical engineering.

Keywords: confined RPC, high-strength spiral steel bars, stress-stain relationship, axial compression, ductility

Исследовано воздействие осевого сжатия на механические свойства круглых колонн из порошкового бетона (Reactive Powder Concrete (RPC), которые обвиты по спирали металлическими волокнами. Сделаны оценки режимов разрушения RPC колоны при осевом сжатии, определена нагрузка-смещение и характеристики металлических волокон. Результаты показывают, что максимальное сжатие для 250 мм диаметра круглой колонны без металлических волокон может быть до $144.4 \mathrm{MPa} \mathrm{c} \mathrm{режимом} \mathrm{хрупкого} \mathrm{разрушения.}$ Увеличение соотношения объема и количества металлических волокон может увеличить пиковые нагрузки до $180 \mathrm{MPa}$, однако пластичность при этом не увеличивается. Полученное соотношение напряжение-деформация для RPC хорошо согласуется с конкретной моделью Мандера и может быть использовано в инженерной практике.
\end{abstract}


Ming-Yang Chen et al. / Experimental study on mechanical behavior of ...

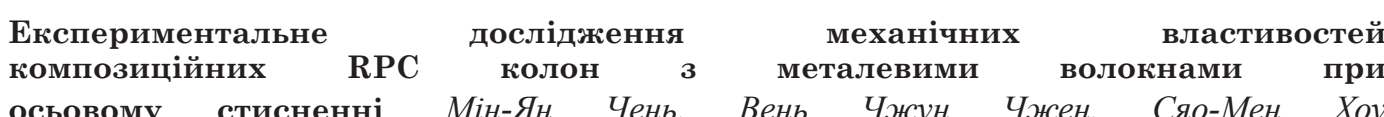

осьовому стисненні. Мін-Ян Чень, Вень Чжун Чжен, Сяо-Мен Хоу

Досліджено вплив осьового стиснення на механічні властивості круглих колон 3 порошкового бетону (Reactive Powder Concrete (RPC), які оповиті по спіралі металевими волокнами. Зроблено ощінки режимів руйнування RPC колони при осьовому стисненні, визначено навантаження-зміщення і характеристики металевих волокон. Результати показують, що максимальне стиснення для круглої колони діаметром 250 мм без металевих волокон може бути до $144,4 \mathrm{MPa} 3$ режимом крихкого руйнування. Збільшення співвідношення обсягу і кількості металевих волокон може збільшити пікові навантаження до $180 \mathrm{MPa}$, однак пластичність при цьому не збільшуеться. Отримане співвідношення напруга-деформація для RPC добре узгоджуеться з конкретною моделлю Мандера і може бути використано в інженерній практиці.

\section{Introduction}

Reactive Power Concrete (RPC)[1,2], developed by BOUYGUES in France in 1993, is a kind of new cement-based composite with excellent strength, high toughness, high durability and good volume stability. RPC which has compressive strength of $200 \sim 800 \mathrm{MPa}$ is one of the new developing directions in ultra-high performance concrete (UHPC) field, and the important initiatives for energy saving and green building materials. It has a wide range of applications in the ocean, oil, nuclear power, the military facilities and other industrial and civil engineering. It has been applied in Canada Sherbrook pedestrian bridge [8], Shepherds Gully Creek Highway Bridge in Australia [9], the new French Jean Bouin Stadium [11], Tokyo International Airport D runway expansion project [13], Fifth Ring Road of Beijing, Qinghai-Tibet Railway [12], Harbin High Speed Railway [14] and Changsha Kaifu District Beichen Delta Hengsi Road Crossing Street Bridge and other domestic and foreign projects. In China, Tsinghua University [3], Harbin Institute of Technology [4], Hunan University [5] and Beijing Jiao Tong University[6] and many other research institutions have carried out basic research of RPC200-grade preparation, production technology and basic mechanical properties[7], and have formulated a national standard of Reactive Powder Concrete(GB/T $31387-2015)$ rules which laid the foundation for the comprehensive promotion of RPC.

RPC has the advantages of high strength and durability, but it is the same as the inherent defects such as high brittleness of highstrength concrete, so it's difficult to be directly applied to structural members with ductile seismic performance. The research results of high-strength concrete columns show that the ductility of high-strength concrete can be effectively improved and the brittle failure can be avoided by setting the stirrups to produce passive restraint, which produces the binding force caused by the lateral expansion of concrete and the deformation of stirrups[15]. Therefore, according to the stirrup configuration and confinement theory of confined high-strength concrete, the axial compression performance test of RPC with high-strength stirrups confined has been studied including the mechanical properties of confined RPC and the measures to improve the ductility of RPC columns, the research provides experimental basis for the engineering applications of RPC column.

\section{Raw Materials and Mix proportions}

The ternary cementing material include cement(C), silica fume (SF) and fly ash (FA). The cement is from Tangshan Jidong P.052.5grade ordinary Portland cement, S94-grade silica fume produced in Shanghai Tian Kai Company, grade I fly ash produced in Beijing ShangLianShouFeng Building Materials Co. Ltd. In order to improve the flow ability of RPC, the ultrafine, smooth spherical particles of nano-beads(N-B) [16] , whose average particle size is $1 / 20(\leq 1.00)$ of fly ash, are used to partly replace the fly ash as a cementing material, the compressive strength of spherical particles is more than $800 \mathrm{MPa}$. We select high purity quartz sand (S) which is $40 \sim 80$ mesh and $80 \sim 140$ mesh produced in Henan Green and the Source of Environmental Protection Co.

Table 1 the optimization mix proportion of RPC

\begin{tabular}{|c|c|c|c|c|c|c|}
\hline W/B & C & SF & FA/N-B & S & water-reducing agent & Steel fiber \\
\hline 0.16 & 1 & 0.3 & $0.15 / 0.15$ & 2 & $1.5 \%$ & $2 \%$ \\
\hline
\end{tabular}

Note: The number in table is volume fraction only for steel fiber, the rest are mass fraction. 
Table 2 specimen parameters and measurement results

\begin{tabular}{|c|c|c|c|c|c|c|c|c||}
\hline \multirow{2}{*}{ No. } & \multicolumn{3}{|c|}{ Hoops } & \multirow{2}{*}{$\begin{array}{c}P_{\text {Max }} \\
(\mathrm{KN})\end{array}$} & $\begin{array}{c}\Delta\left(P_{\text {Max }}\right) \\
(\mathrm{mm})\end{array}$ & $\begin{array}{c}\Delta\left(0.85 P_{\text {Max }}\right) \\
(\mathrm{mm})\end{array}$ & $\begin{array}{c}\varepsilon_{s v} \\
\left(\mathrm{x} 10^{-6}\right)\end{array}$ & $\begin{array}{c}\varepsilon_{s} \\
\left(\mathrm{x} 10^{-6}\right)\end{array}$ \\
\cline { 2 - 9 } ACS1 & -- & -- & 0 & 7090.0 & 0.973 & & \\
\hline ACS2 & 6 & 75 & 0.69 & 7287.0 & 1.020 & & 437 & 4074 \\
\hline ACS3 & 6 & 50 & 1.04 & 7365.0 & 1.073 & 1.294 & 1020 & 4123 \\
\hline ACS4 & 6 & 35 & 1.48 & 7486.0 & 1.103 & 1.544 & 1160 & 4176 \\
\hline ACS5 & 6 & 20 & 2.59 & 7691.6 & 1.152 & 1.847 & 1543 & 4205 \\
\hline ACS6 & 10 & 35 & 4.27 & 8197.5 & 1.205 & 2.273 & 1820 & 4463 \\
\hline ACS7 & 12 & 35 & 6.27 & 8933.9 & 1.372 & 1.294 & 2120 & 5178 \\
\hline
\end{tabular}

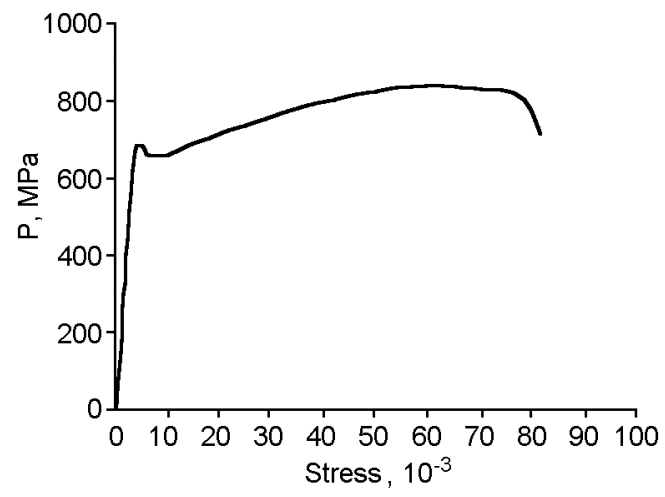

Fig. 1. Stress-strain curve of HRB600 steel

Ltd as aggregates. Steel fiber(F) was selected from ultra-fine and ultra-short copper-coated microfiber steel fiber from Anshan ChangHong steel fiber factory. Steel fiber has diameter of $0.20 \mathrm{~mm}$, length of $13 \mathrm{~mm}$ and tensile strength of $2850 \mathrm{MPa}$. Super plasticizer is selected from the AN4000 polycarboxylic acid-based high-performance water-reducing agent developed by Beijing Institute of Architectural Engineering; it has solid content of $39.47 \%$, water reduction rate of $39 \%$ and yellow brown color. In order to improve the strength of RPC, many mixing trials were attempted by the low water to cement ratio as 0.16 . The optimization mix proportion under the conditions to ensure the liquidity as seen in Table 1 , under the $200^{\circ} \mathrm{C}$ high temperature and the $1.3 \mathrm{MPa}$ high pressure curing, the $70.7 \times 70.7 \times 70.7 \mathrm{~mm}$ cubic strength is up to $215 \mathrm{MPa}$.

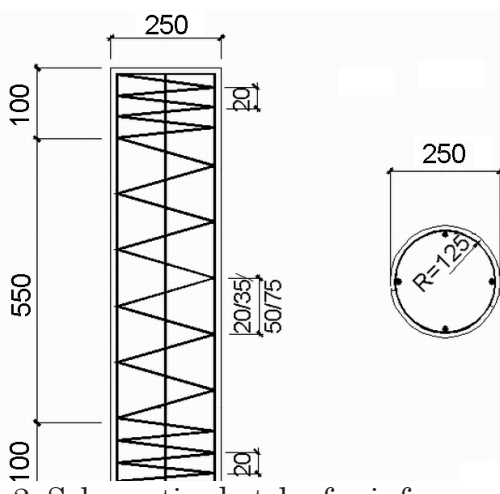

Fig. 2. Schematic sketch of reinforcement in axial compression specimen

\section{Experiment Investigation}

\section{A. Specimen Design and fabrication}

The specimens were 7 cylinders with the slenderness ratio $\frac{l_{o}}{d}=3$, and so the diameter is $250 \mathrm{~mm}$ and $750 \mathrm{~mm}$ in height. The HRB600grade high strength steel bars from Tangshan Iron and Steel Group Co. Ltd were used as spiral stirrups by the maximum stirrup spacing $75 \mathrm{~mm}$ for confining the RPC, and the volume stirrup ratio was between $0 \%$ and $6.27 \%$. The longitudinal reinforcements were four HRB600grade high strength steel bars with $10 \mathrm{~mm}$ diameter. The cover is $10 \mathrm{~mm}$. The stress-strain curve of HRB600-grade high strength steel is shown in Figure 1, and the specimen parameters are shown in Table 2 and Figure 2. 


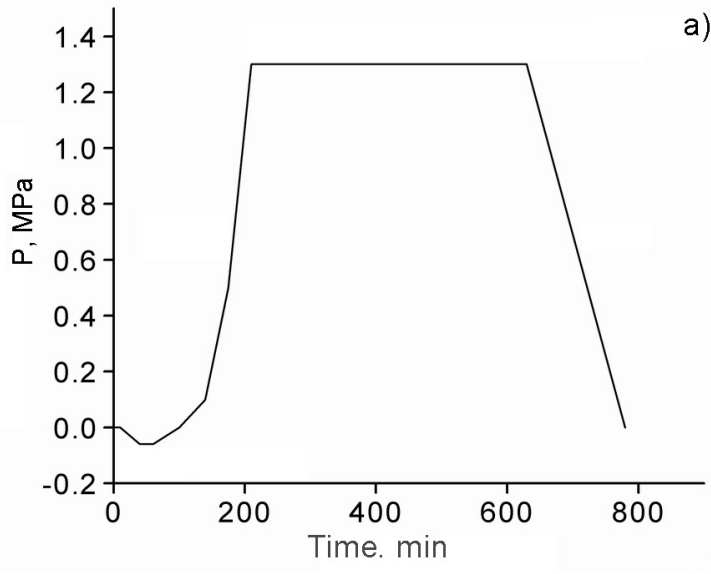

b)

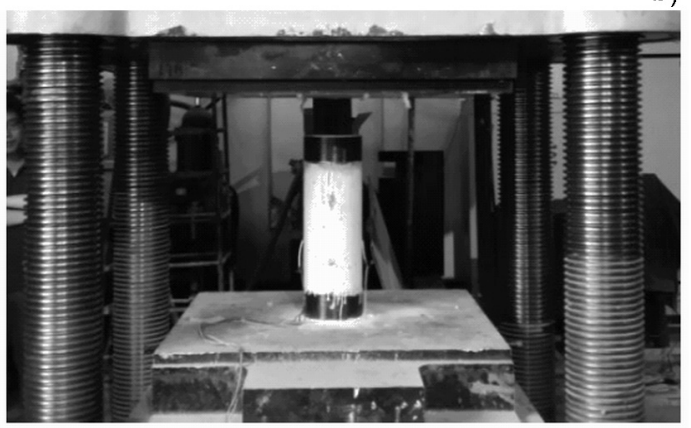

Fig. 3. a) Time-pressure curve of autoaclave; b) $20000 \mathrm{kN}$ electro-hydraulic servo pressure tester

According to the characteristics of RPC which has small particle size and the larger unit weight than normal concrete, a 100L singlehorizontal-axis forced mortar mixer was made, the thickness of the steel plate of the mixing shaft was increased from $6 \mathrm{~mm}$ to $10 \mathrm{~mm}$, and the gap between the shaft and the container is reduced to $3 \sim 5 \mathrm{~mm}$, in the meantime, the motor power is increased from $3 \mathrm{~kW}$ to $4 \mathrm{~kW}$ for ensuring sufficient power to mix adequately. At first the cementing material and quartz sand (S) were put together for mixing $4 \mathrm{~min}$, and then the entire water-reducing agent and 50\% water were mixed $6 \mathrm{~min}$, and then adding the remaining 50\% water for $4 \mathrm{~min}$, and finally put the steel fibers for $4 \mathrm{~min}$. The mixture has sufficient liquidity, good scalability so that can satisfy pouring conditions.

In order to stimulate the raw materials further activity such as silica fume and fly ash and improve the compaction and strength of RPC, the technology of making autoclaved lime-sand brick was used for RPC curing, and the process of autoclave included vacuumizing, boosting, constant temperature and pressure (1.3MP and $200{ }^{\circ} \mathrm{C}$ ) and depressurization (Figure 3 ).

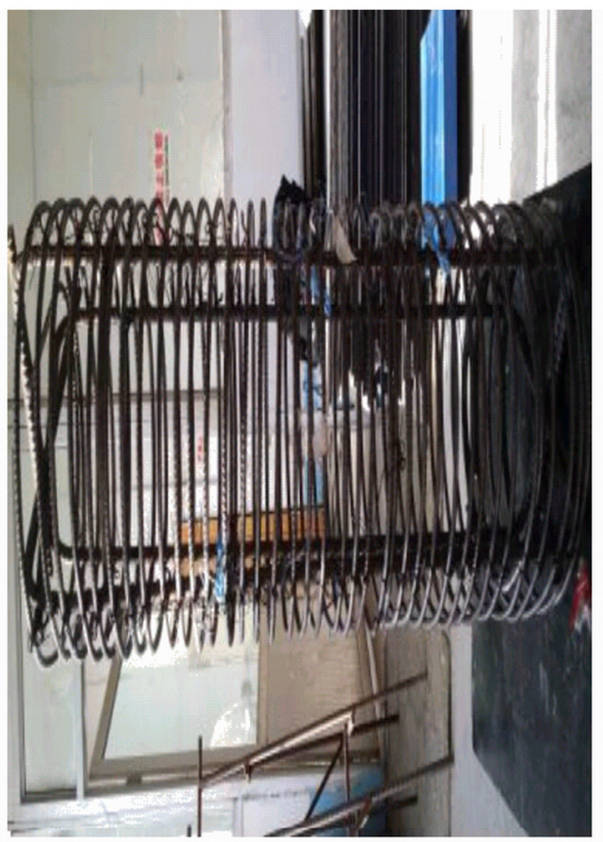

Fig. 4. Arrangement of the measurement device

\section{B. Loading and Measurement}

The test was carried out with a $20000 \mathrm{kN}$ long column microcomputer controlled electro-hydraulic servo pressure tester (Figure 4) in Beijing University of Civil Engineering and Architecture according to the Standard for Test Methods for Concrete Structures (GB/T501522012). To ensure that the specimen is in axial compression state, it is geometrically and physically centered with $10 \%$ preloading before loading. After the completion of the alignment, firstly use force grading to load with rate of $300 \mathrm{kN} /$ min and hold 2mins; when loading to $70 \%$ of the estimated capacity, transfer into displacement grading to load with the rate of $0.05 \mathrm{~mm} / \mathrm{min}$. After the peak load is exceeded, the displacement loading rate is adjusted to $0.1 \mathrm{~mm} / \mathrm{min}$ until the specimen is completely failed.

According to the principle of Saint-Venant, two dial gauges with range of $10 \mathrm{~mm}$ are arranged symmetrically at the height of $250 \mathrm{~mm}$ in the middle of the specimen for measuring the axial deformation of the specimen. At the same time, on the stirrups of the specimen and longitudinal reinforcement, BA120-5AA-type strain gauges that resist $250{ }^{\circ} \mathrm{C}$ high temperatures and produced by Beijing YiYang test company is pasted, they are used to measure the internal stirrups and longitudinal reinforcement strain. On the outer surface of the concrete, two longitudinal and two transverse concrete strain gauges are arranged symmetrically to measure the longitudinal strain and transverse deformation of the outer surface of the specimen. The 


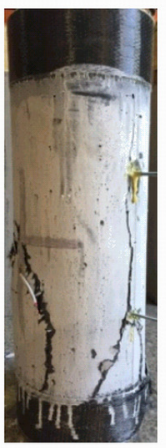

ACS1

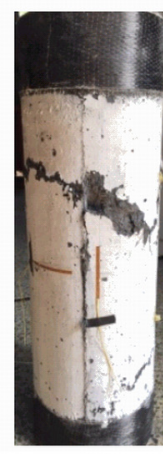

ACS2

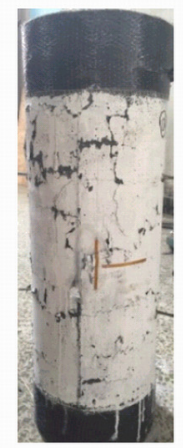

ACS3

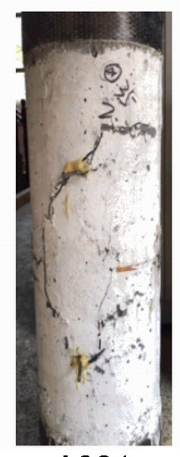

ACS4

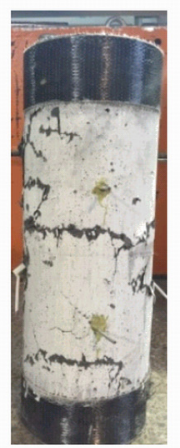

ACS5

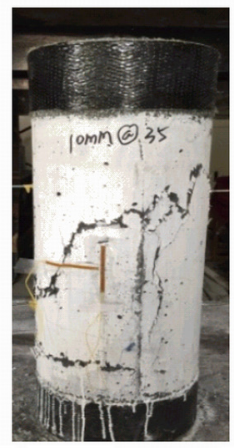

ACS6

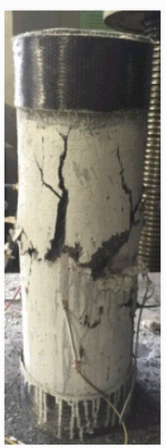

ACS7

Fig. 5. Specimen failure mode

dial indicators and strain gauges are arranged as shown in Fig 4. The strains data were picked by DH-3820 static resistance test system. The axial force of the specimen was got in real time by the control software of electro-hydraulic servo testing machine. The dial indicator was read and recorded after the deformation data loading in each grade seems stable.

\section{Results and Discussions}

\section{A. Failure mode}

For the plain RPC specimen ACS1 with no longitudinal reinforcement and stirrups, before loading to $5387 \mathrm{kN}$, the cracks did not appear on the surface and the vertical deformation increased proportionally, so it was in the elastic phase. As the load increased, the internal accumulated energy increased, internal mixed steel fiber slipped or was pulled off, which caused crisp sound, on the surface small debris "collapsed" out continuously, and thus the continuous cracks gradually formed. When reaching the ultimate load of $7090 \mathrm{kN}$, the bearing capacity decreased sharply and brittle failure instantly happened to terminate the test. At this point, the crack concentrated across the bottom of the column, the maximum crack width has reached $8 \mathrm{~mm}$.

For the cylinder ACS2 4 with low stirrup ratio, because of the constraint of the stirrups, the formation of the vertical cracks was prevented. When it was destroyed, many places was slightly cracked on the outer surface of the ACS2 4, and the whole protective layer didn't fall off. The appearance of specimen was destroyed more lightly than that of specimen ACS1, and the volume expansion is not obvious. The cracking load for ACS2 4 is 6000 $\sim 6600 \mathrm{kN}$, which is slightly higher than that of ACS1. The ultimate load is also increased slightly and ductility increased gradually.

For the cylinder ACS5 $\sim 7$ with high stirrup ratio, after attaching the ultimate load, be- cause of strong stirrup constraint, the bearing capacity of specimen did not decrease rapidly and the descending section tended to be gentle. When the ASC7 was damaged, the middle part of the specimen expanded obviously, the protective layer fell off and the ring cracks formed. The failure form of each specimen is shown in Fig 5.

\section{Load-displacement and stress-strain} relationships

The load-displacement curve and stressstrain curve of the specimens are shown in Figure 6 and Figure 7, which are divided into three stages: elasticity, elastic-plasticity and descent.

Begin to load up to $70 \%$ of the ultimate load is the elastic period. At this time, the vertical deformation increases linearly with the load, the transverse deformation of the specimen is small, the effect of the stirrup constraint is not obvious, the volume stirrup ratio has little effect on the stiffness, and the rising section of the curve for the specimen is almost the same.

Subsequently the specimen is entering into the elastic-plastic period, in which the crack de-

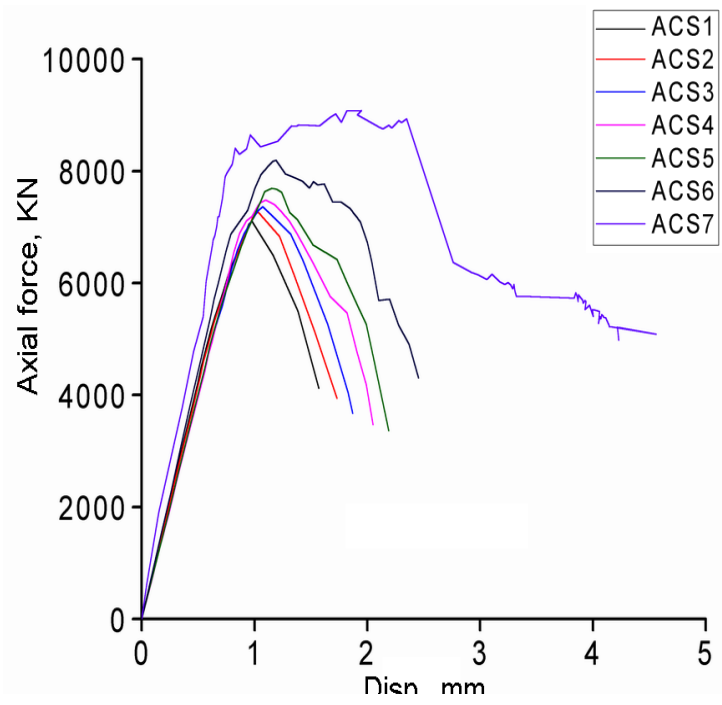

Fig. 6. Curve of load-displacement relationship of specimen 


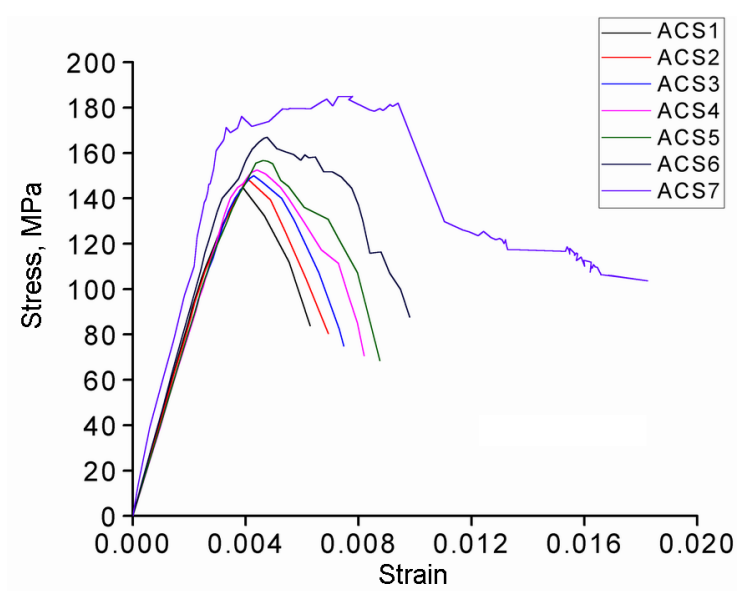

Fig. 7. Stress-strain curve of the specimen

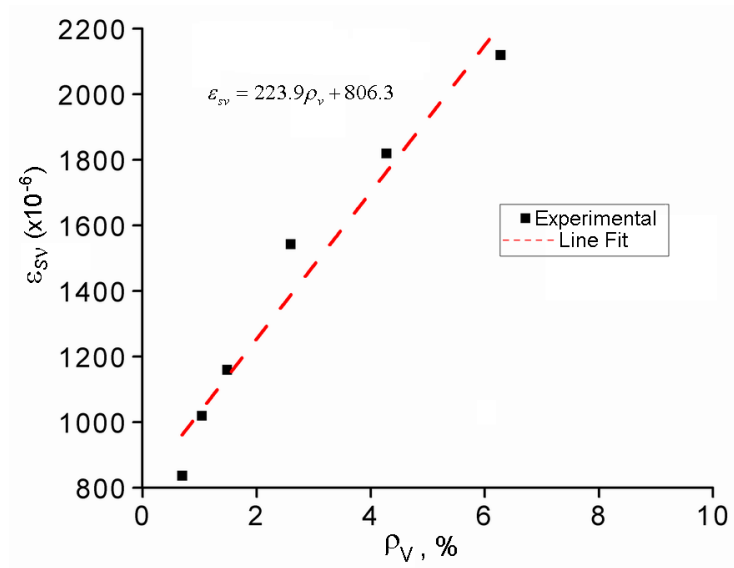

Fig. 8. Volume stirrup ratio and strain of stirrup at the peak

velops and the transverse expansion increases. The restraint effect of the stirrup on the core $\mathrm{RPC}$ is enhanced. The peak load and the peak deformation increase with the increase of the volume stirrup ratio, but the degree that peak stress has improved is lower than that of the peak strain, which indicates that the increase of the stirrup ratio is more effective for ductility improvement.

After reaching the ultimate load, the curve begins to decline. With the increase of volume stirrup ratio, the curve decreases gently, the ductility of specimen was improved and the capacity of deformation becomes better.

\section{Measurement for high-strength stir- rup stress}

The average strain of the stirrups in Table 2 shows that the high-strength stirrups did not yield when all the specimens reached the peak load, because RPC has a low water-binder ratio, high compactness, and there is almost no voids between the gel and aggregate, also the random distribution of the steel fibers play a further role on preventing the development of

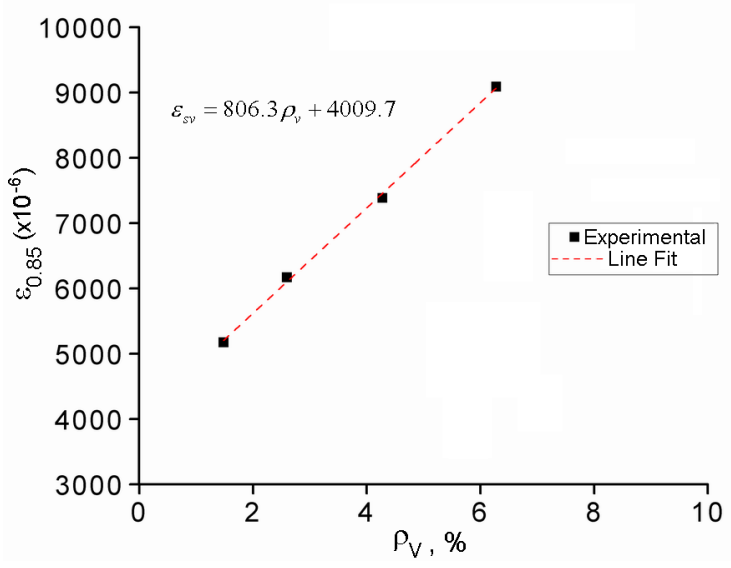

Fig. 9. The stirrup strain at the peak value

cracks and lateral deformation, and the measured Poisson ratio of RPC in elastic phase is between 0.16 to 0.19 , lateral expansion deformation is smaller than ordinary concrete. However, with the increasing of the stirrup ratio, the degree of confinement increases and the peak stress and peak strain increase, and the corresponding strain of high-strength stirrup also increase gradually. The fitting relationship between the volume stirrup ratio and the stirrup strain at the peak value is shown in Figure 8. Figure 9 shows measured strain of stirrup and its fitting equation of the specimen ACS $4 \sim 7$ in the descending section under $85 \%$ peak load.

\section{E. Peak stress and peak strain for con-} strained RPC

Data processing and analysis of test results in Table 1 were performed. Table 3 gives the peak strain, peak stress and the lateral restaint stress generated by stirrups and other test results. As can be seen in Table 3, the peak strain of plain RPC is $3820 \mu \varepsilon$, higher than the ordinary concrete of $2000 \mu \varepsilon$, and thus the highstrength steel whose strength is lower than $760 \mathrm{MPa}$ can be used as a compression longitudinal reinforcement and can fully play a role. The limit strength of the concrete column confined by the spiral stirrups in the Code for Design of Concrete Structures (GB50010-2010)in China applies the linear relationship between the peak stress $f_{c c}$ and the lateral binding stress $\sigma_{1}$ of confined concrete put forward by Considere and Richart:

$$
\begin{aligned}
& \frac{f_{c c}}{f_{c}}=4 \frac{\sigma_{1}}{f_{c}}+1 \\
& \frac{\varepsilon_{c c}}{\varepsilon_{c}}=5 \frac{\sigma_{1}}{f_{c}}+1
\end{aligned}
$$

Therefore, the actual lateral restraint stress of RPC is calculated by the measured average strain of stirrups in Table 2, then the fitting 


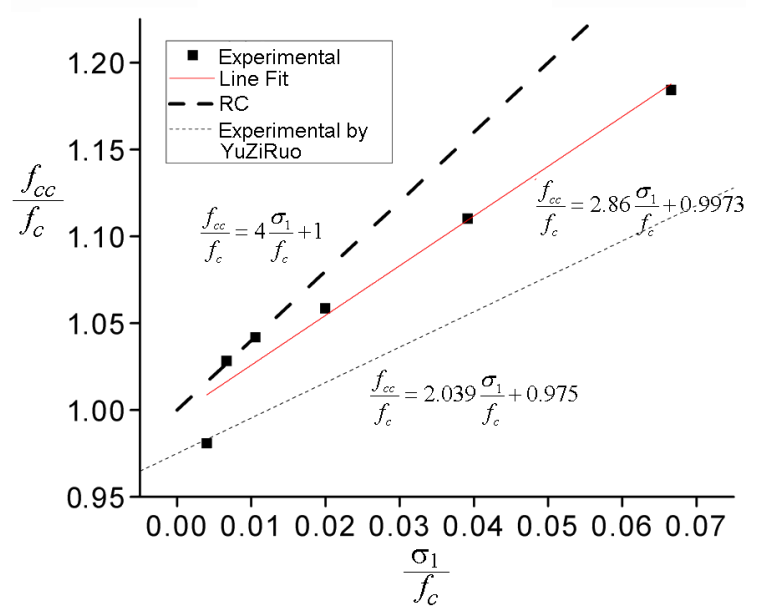

Fig. 10 Relationship between lateral binding stress and peak stress of stirrups

relationship among the peak stress $f_{c c}$, peak strain $\sigma_{c c}$ and the lateral binding stress $\sigma_{1}$ of the confined RPC is shown in Figure 10 and Figure 11. According to Figure 10, it can be seen that the ratio of lateral restraint stress to the peak stress is 2.86 , which is smaller than that of ordinary concrete. It indicates that the RPC peak stress fcc increases more slowly with the lateral restraint $\mathrm{g}$ stress than ordinary concrete, which is mainly owing to that RPC has a higher compactness than ordinary concrete, the gap between the cementitious material and the aggregate is small, and the steel fiber has a strong restraint effect on the RPC substrate itself. When the damage develops inside the substrate, the development of tensile cracks is relatively difficult, under such conditions, the improvement effect that lateral binding stress

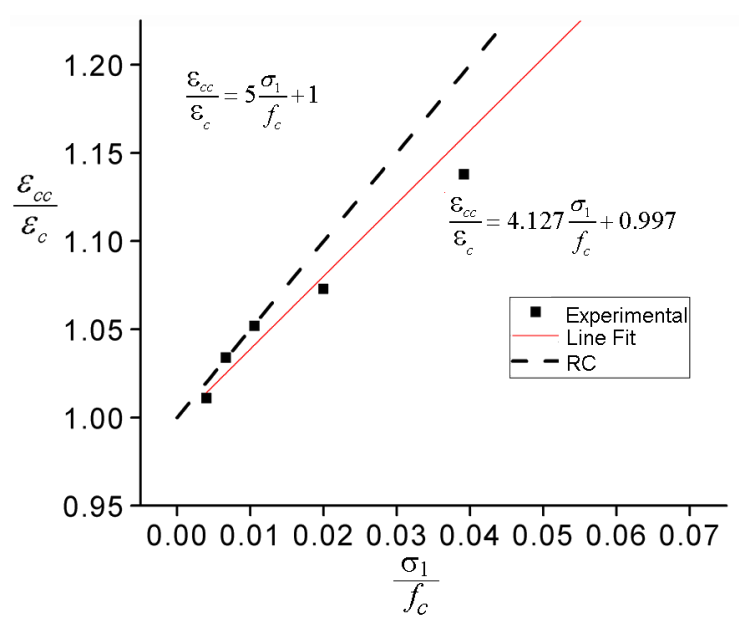

Fig. 11. Relationship between lateral binding stress and peak strain of stirrups

has on the compressive strength of RPC is not as obvious as ordinary concrete. The same conclusion is also given by Yu Ziruo et al.[24] in the conventional tri-axial compression tests under different confining pressures by RPC. But the confining pressure range is $0-0.4 f_{c}$, which is larger than the maximum lateral restraint stress of $0.09 f_{c}$ in this paper. The ratio of lateral binding stress to peak stress they have got is 2.039, which is less than the fitting value of 2.86 in this paper. This conclusion is consistent with the opinion proposed by Richart that is when the lateral restraint stress is small, the value of $k$ is overlarge.

\section{F. Constrained RPC Stress - Strain Re-} lationship Curve

Since Considere used spiral stirrups to effectively restrain the axial compression column for

Table 3. Test results analysis

\begin{tabular}{|c|c|c|c|c|c|c|c|c|}
\hline No. & $\begin{array}{c}\varepsilon_{c c} \\
\left(\mathrm{x} 10^{-6}\right)\end{array}$ & $\begin{array}{c}\varepsilon_{0.85} \\
\left(\mathrm{x} 10^{-6}\right)\end{array}$ & $\frac{\varepsilon_{c c}}{\varepsilon_{c}}$ & $\frac{\varepsilon_{c c}}{\varepsilon_{0.85}}$ & $\begin{array}{c}f_{c c} \\
(\mathrm{MPa})\end{array}$ & $\sigma_{1}$ & $\frac{\sigma_{1}}{f_{c}}$ & $\frac{f_{c c}}{f_{c}}$ \\
\hline $\mathrm{ACS} 1$ & 3892 & -- & & & 144.44 & & & \\
\hline ACS2 & 4080 & -- & 1.05 & -- & 148.45 & 0.575 & 0.004 & 1.028 \\
\hline ACS3 & 4292 & -- & 1.10 & -- & 150.04 & 1.051 & 0.007 & 1.039 \\
\hline ACS4 & 4412 & 5177 & 1.13 & 1.173 & 152.50 & 1.707 & 0.012 & 1.056 \\
\hline ACS5 & 4608 & 6175 & 1.18 & 1.340 & 156.69 & 3.974 & 0.028 & 1.085 \\
\hline ACS6 & 4820 & 7388 & 1.24 & 1.533 & 167.00 & 7.725 & 0.053 & 1.156 \\
\hline ACS7 & 5486 & 9092 & 1.41 & 1.657 & 182.00 & 13.209 & 0.091 & 1.260 \\
\hline
\end{tabular}



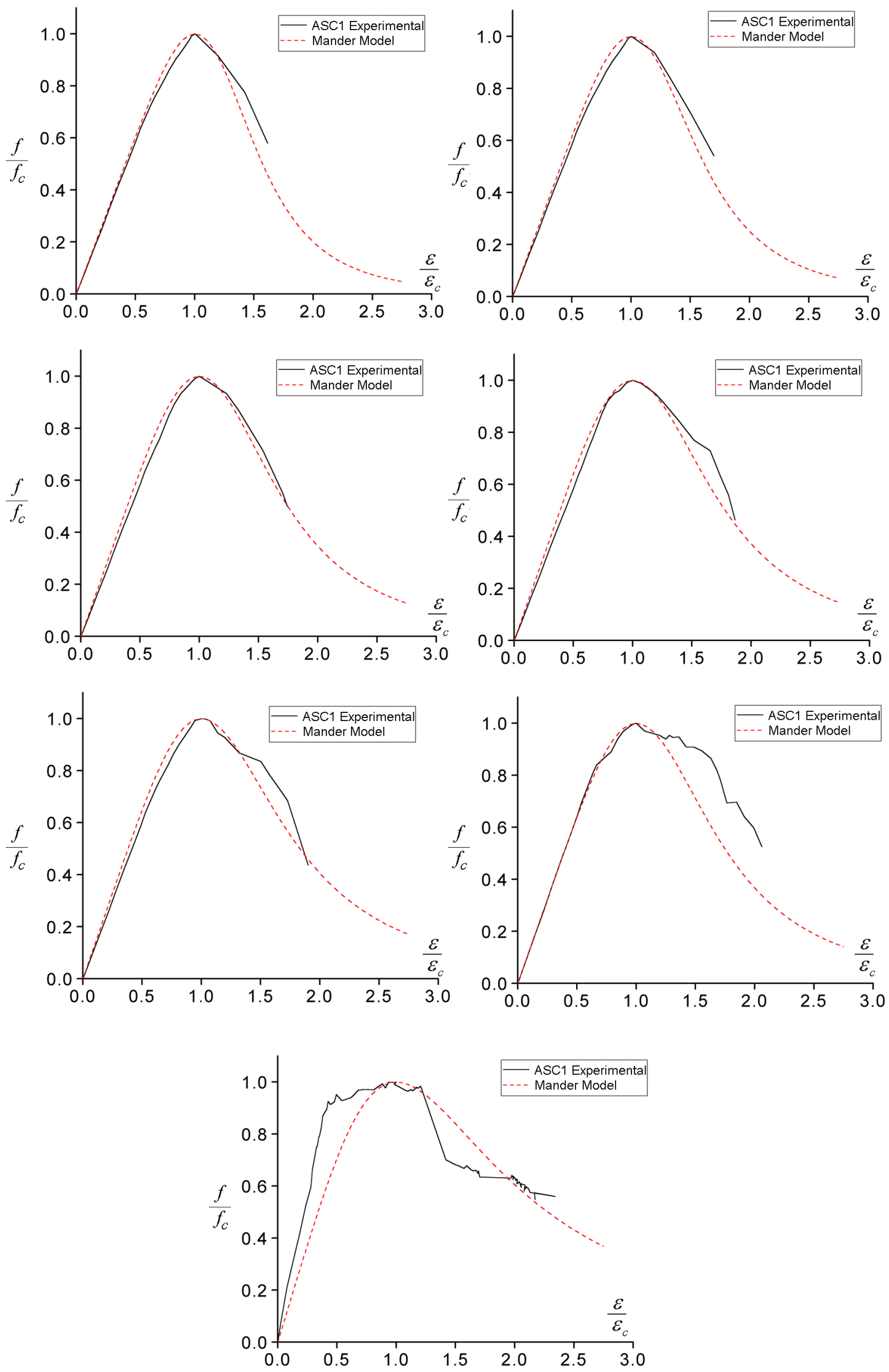

Fig. 12. Comparison of measured stress-strain curves and Mander Model 
the first time in 1903, the research of confined concrete has been done for more than 100 years. Many stress-strain constitutive models have been put forward such as Mander model, Sheikh model, Park model, Kent-Park model, Zhang Xiuqin model and Saatcioglu model[24]. While the Mander model [25] gives a curve equation which is applicable to rectangular stirrups, spiral stirrups and stirrups and has a uniform rising and descending section. The skeleton curve has fewer parameters and a clear physical meaning, and has been widely applied. In this paper, the measured stress-strain curves are compared with the Mander model, as shown in Figure 12. It can be seen from Figure 12 that the Mander model is in good agreement with the experimental curve and has a higher accuracy in the rising section. In the descending period, the bearing capacity of Mander model is slightly lower than the experimental value. Therefore, the Mander model can be conservatively used to simulate the stress-strain relationship of constrained $\mathrm{RPC}$, so that the unity with the confined concrete can be achieved.

\section{Conclusions}

1) The peak strain of plain RPC is $3820 \mu \varepsilon$, at the occasion where the high-strength steel which has the strength less than $760 \mathrm{MPa}$ is used as a compression longitudinal reinforcement, RPC can fully usable. High-strength stirrups do not yield when reaching their peak loads. The actual restraint stress can be calculated with reference to Figure 12. But when the bearing capacity of the specimen enters into the descending section, the high-strength stirrups can continue to effectively constrain the RPC and bring their superiority of high strength to fully play, and then make the decline gentler, so that the ductility of the specimen can be improved.

2) The peak stress and peak strain of RPC both have linear proportional relationship with lateral binding stress and the proportion coefficient is 2.86, smaller than that of ordinary concrete. During the calculation process of bearing capacity, the proportion coefficient can be taken as 2, according to the Code for Design of Concrete Structures (GB50010-2010), the bearing capacity of RPC columns with spiral stirrups confined can be calculated using the following formula:

3) The stress-strain relationship of confined RPC can be calculated using the classical ordinary Mander model. The RPC with spiral stirrups confined can effectively improve the duc- tility of RPC columns, and its bearing capacity is much higher than that of ordinary concrete, which is significant for energy saving, emission reduction and green development.

\section{References}

1. P. Richard, M. Cheyrezy, Composition of reactive powder concretes[J]. Cem.Concr. Res., 25(7), 1501, 1995,

2. P. Richard, M. Cheyrezy, ACI Special Publ., 144, 507, 1994.

3. Weizu Qin, Pet. Eng. Constr, 28(3), 1, 2002.

4. Wenzhong Zheng, Li Li, J. Hunan Univ. (Science), 36(2), 13, 2009.

5. Feng He, Zhengyu Huang, J. Hunan Univ. (Science), 28(2), 89, 2001.

6. Guangjie Yan, Guiping Yan, Mingzhe An, J. China Railway Soc., 26(2), 116, 2004.

7. Wenzhong Zheng, XueYuan Lv, J. Build. Struct., 36(10), 44, 2015.

8. Blais P Y, Couture M, PCI, 44, 60, 1999.

9. B.Cavill, G. Chrigwin, CIA 21th Bi-ennial Conference, Brisbane, 2003, p 1.

10. M. Behloul, K.C. Lee, Struct. Concr., 4(4), 195, 2003.

11. P.Mazzacane, R. Ricciotti, G. Lamoureux, et al. Intern. Symp. Perform. Fibre-Reinf. Concrete, Marseille, RILEM Publ., 2013, p.59.

12. Jianxin Lu. Shanxi, Province China Railway First Group Co., Ltd.

13. H. Musha, H. Ohkuma, T. Kitamura, Intern. Symp. Ul-tra-High Perform. Fibre-Reinf. Concrete, Marseille, RILEM Publ, 2013, p 17.

14. Ping Yu. J. Shan. Arch., 36(12),309, 2010.

15. Qingxuan Shi, Kun Yang, Weiya Liu, J. Eng .Mech., 29( 1), 141, 2012

16. Feng Hao Li, J Concrete Cement Prod, 5, 13, 2010

17. Yanhai Wu, Yanbin He, China J. Highway Trans, 16(4), 44, 2003.

18. Tao Shi, Baochun Chen, Huisheng Shi, J. Mater. Sci. Eng., 23(6): 867,2005.

19. Guangcheng Long, Youjun Xie, Zhengwu Jiang, Zhenping Sun, Peiming Wang, J. Build. Mater., 7(3), 269, 2004.

20. V Candrlic, J Bleiziffer, A Mandic, Proceed. Third Intern. Conf. Arch Bridge[C]. Paris,France, 2001, p. 695,.

21. Lijun Zhang, Mingzhe An, Guiping Yan. World Sci-Tech. $R$ \& D, 27(6), 49,2005.

22. Zhiping Chen, Zhi Fang, Kuangyi Zhang, Jianhua Hu, J.China Foreign Highway, 31(6), 16, 2011.

23. Ziruo Yu, Xin Qin, Mingzhe An, China Railway Scie., 33(2): 38, 2012

24. Wenfeng Zhou, Zongming Huang, Shaoliang Bai, J.Chongqing Univ. Arch. Civilengin., 25(4),121, 2003

25. J.B .Mander, M.J .N.Priestley, R.Park. ASCE, 8, 1804, 1988 